\title{
Systematic Review on The Factors That Influence Well-Being Among Teachers
}

\author{
Tri Na'imah*, Rismatul Kasanah, Putri Salma Rahmasari Qurrota Aeni \\ Faculty of Psychology, Universitas Muhammadiyah Purwokerto, Jl. KH. Ahmad Dahlan, Purwokerto, Indonesia. \\ *Corresponding author: trinaimah@ump.ac.id
}

Article history: Received: 11 January 2020 Received in revised form: 28 June 2020 Accepted: 10 May 2021 Published online: 09 August 2021

\begin{abstract}
Increasing the well-being of teachers in schools is an important issue that needs to be discussed. Nowadays, there are many problems related to the teacher, which will affect the teacher's professionalism in teaching. This systematic review aims to synthesize factors that can impact teacher welfare. The journal search database includes EBSCOHOST, PROQUEST, EmeraldInsight, and ScienceDirect, published in the last ten years (2010-2019). The keywords used are "Welfare" OR "Psychological Welfare" OR "Subjective Welfare" OR "Subjective Welfare" AND Teacher. Article selection uses PICOSS (Population, Intervention, Comparator, Result Variable, Study Design, and Setting). There are three syntheses of predictors of teacher well-being variables, namely personal factors, professional factors, and organizational factors.
\end{abstract}

Keywords: Personal Factors; Professional Factors; Organizational Factors; Well-Being; Teacher

(C) 2021 Penerbit UTM Press. All rights reserved

\subsection{INTRODUCTION}

The implementation of education is one reflection of the quality of a nation; therefore, the quality of the organization of education must be maintained. The application of learning must bring functional changes for creating a broad, equitable, and quality education system for the entire life of a country's people (Hapsari, 2016). The delivery of education is inseparable from the figure of the teaching staff, namely the teacher. The teacher is a designation for positions and professions for someone who devotes himself to education through educative interaction in a patterned, formal, and systematic manner (Shabir, 2015).

Currently, being a teacher is not easy because teachers are required to do their job as well as possible. Therefore, if the teacher does not understand the potential and limitations, it will impact the decline in teacher performance in teaching (Mafazi, 2016). As an educator, teachers are required to carry out the burden of responsibilities and obligations to develop the potential of their students. On the one hand, each teacher's responsibilities and duties have varied mainly due to the different types of education where he works. Many of these burdens and demands are then feared to make teachers not feel prosperous in the workplace (Shabir, 2015).

Several problems relating to teacher welfare, which are later feared, could hinder teachers' creation of professionalism because everyone has different perceptions about welfare(Qudsyi, 2015). Teachers need welfare to support the implementation of various job demands found in schools. In this case, work demands can create pressures that affect teachers' well-being (Wulan \& Putri, 2016). Therefore, researchers currently study a lot about teacher well-being in the workplace by using several terms, including employee and workplace well-being (Burns \& Machin, 2012), teacher well-being; Virtanen, Vaaland, \& Ertesvåg, 2019; Hwang et al., 2019; Graham \& Truscotthttps, 2019; Sasmoko, Herisetyantri, Suroso, \& Ying, 2017), Psychological well-being guru (Liang, Peng, Zhao, \& Wu, 2017). Some of these studies show gaps between studies because there is no common understanding of the teacher's well-being in the workplace, so it is necessary to formulate a clear concept of the teacher's well-being.

Some research results also prove that the well-being of teachers in the workplace is influenced by several factors, including occupational stress (Bahari, Lin, \& Wider, 2016), self-esteem, general self-efficacy, teacher self-efficacy, optimism, and perceived social support (Stanculescu, 2014), workplace spirituality and self-esteem (Awan \& Sitwat, 2014), organizational justice (Elovainio et al., 2011), social support, academic functioning, and social-emotional functioning (Tennant et al., 2015).

The results of the study indicate that the sources of teacher well-being are very diverse. Understanding the factors that influence teacher well-being in the workplace is essential as a reference for the preparation of teacher mental health promotion programs and developing a framework for teacher professional development. So the writing of this article aims to create a synthesis of factors that influence teacher well-being as a framework for educational researchers in education management. 


\subsection{LITERATURE REVIEW}

Many researchers have studied the concept of well-being, but all well-being ideas come from two philosophical schools, namely hedonic and eudaimonia (Deci \& Ryan, 2008). In its development, welfare research is currently dominated by two main approaches: hedonic and eudaimonic (Huta, 2015; Waterman, 1993). The hedonic approach perceives well-being subjectively so that well-being is considered the same as happiness. In contrast, the eudaimonic approach defines well-being as achieved if a person becomes a fully functioning person (Deci \& Ryan, 2008).

Well-being has various definitions developed using different approaches. Danna \& Griffin (1999) use the terms health and work health and well-being comfort to see workplace well-being employees' work comfort. The concept of well-being is widely applied in various fields of life, including in the world of work. Well-being shows employees' welfare as mental, physical, and health, as well as employee satisfaction both at work and outside of work (Danna \& Griffin, 1999).

A teacher's workplace well-being is a positive emotional state that combines students' and teachers' needs and personal expectations. Teacher welfare and job satisfaction greatly influence teacher behavior and are positively related to school and classroom climate and student achievement (Spilt, Koomen, \& Thijs, 2011). Some concepts can be interpreted as the construct of workplace wellbeing, namely job satisfaction, work involvement, organizational commitment, emotional involvement and positive and negative moods at work, intrinsic motivation, and enthusiasm (Fisher, 2014). Furthermore, there are four main dimensions of affective well-being, aspirations, autonomy, and competence. The affective welfare dimension consists of job satisfaction, organizational commitment, tension at work, and fatigue.

In contrast, the dimension of aspiration is the ability of individuals to achieve challenging goals at work. The autonomy dimension is related to employees' strength to meet the demands of the work environment independently. In contrast, the competency dimension contains aspects of employee self-efficacy towards their work (Warr, 1994). Based on this description, it can be concluded that workplace well-being is multidimensional.

In the world of education, the concept of workplace well-being teachers is defined as a sense of fulfillment of professional assignments, job satisfaction, the achievement of goals, and happiness built in collaboration with fellow teachers and students (Acton \& Glasgow, 2015). Thus, to achieve well-being, the teacher involves the cooperation of professionalism and the relationship between the teacher and students. The concept of workplace well-being was developed based on Herzberg's motivation theory of hygiene which explains that individuals work based on intrinsic and extrinsic motivation (Page, 2005). Based on this concept, Page (2005) developed workplace well-being dimensions into two dimensions, namely the intrinsic dimension and the extrinsic dimension. The intrinsic dimension consists of responsibility in work, the meaning of work, independence at work, use of abilities at work, and feelings of achievement at work. Meanwhile, the external dimension consists of adequate time, working conditions, supervision, promotion opportunities, recognition and appreciation of work results, wages, job security.

In the world of education, the concept of teacher workplace well-being is defined as a sense of professional duty fulfillment, job satisfaction, goal achievement, and happiness built in a collaborative process with fellow teachers and students (Acton \& Glasgow, 2015). Emotional and cognitive forces related to the dimension of well-being are hope, enthusiasm, gratitude, and forgiveness (Forest, Mageau, Crevier-braud, Bergeron, \& Dubreuil, 2012). In Indonesia, the most dominant dimension determining teacher welfare is the cognitive dimension. This condition is also influenced by the strength of family support (Sasmoko et al., 2017). These dimensions are explained in indicators of teacher well-being, including 1) workload well-being, related to workload problems and work pressure, 2) organizational well-being, compared to teachers' perceptions of school organizations as organizations including perceptions of school leadership and teaching ability, 3) student interaction well-being, related to teacher interaction with students (understanding of student behavior, motivation) (Collie, Shapka, Perry, \& Martin, 2015). This description shows that the reciprocal relationship between teacher and student becomes an essential source for achieving well-being. Thus, it appears that the teacher's well-being workplace is related to professional, organizational, and social relations aspects. Therefore, the review's systematic objective is to synthesize predictor variables from wellbeing teachers in schools.

\subsection{METHODOLOGY}

\section{Literature Search}

The process of finding articles that are done through an electronic database used is EBSCOHOST, PROQUEST, EmeraldInsight, and ScienceDirect. The keywords used are "Well-being" OR "Psychological Well-being" OR "Subjective Well-being" AND "Teacher." Article selection uses the PICOSS table (Dundar \& Fleeman, 2017). PICOSS (Population, Intervention, Comparative, Results Variable, Study Design, and Arrangement) is used to determine detailed, clear, and relevant inclusion and exclusion criteria related to the systematic review question's essential components. Tables arranged based on PICOSS can help reviewers, especially in finding articles.

\section{Inclusion and Exclusive Criteria}

After searching for various articles, then we made criteria according to the PICOSS Table below. Table 1 helps review, especially in article searches. 
Table 1 Table PICOSS

\begin{tabular}{lll}
\hline Criteria & Inclusive & Exclusive \\
\hline Population & Teacher & employees other than teachers \\
\hline Intervention & - & - \\
\hline Comparison & - & - \\
\hline Output & $\begin{array}{l}\text { Factor-based results that affect the } \\
\text { well-being of teachers }\end{array}$ & Products do not fit the research \\
\hline Design study & Quantitative & $\begin{array}{l}\text { Beyond quantitative } \\
\text { research }\end{array}$ \\
\hline
\end{tabular}

Based on these criteria, the samples used are in the following Table 2.

Table 2 Data characteristics

\begin{tabular}{|c|c|c|c|}
\hline No. & Predictor variable & Population & Reference \\
\hline 1. & Workplace Spirituality & Teacher of Engineering & (Aboobaker, 2019) \\
\hline 2. & Workplace Spirituality & An elementary teacher in India & (Mahipalan \& Sheena, 2018) \\
\hline 3. & Leadership and gender & $\begin{array}{l}\text { Elementary school teacher and } \\
\text { middle school teacher }\end{array}$ & $\begin{array}{l}\text { (Konu, Viitanen, \& Lintonen, } \\
\text { 2010) }\end{array}$ \\
\hline 4. & Mentoring experience & Teacher in Canada & $\begin{array}{c}\text { (Kutsyuruba, } \text { Godden, \& } \\
\text { Bosica, 2019) }\end{array}$ \\
\hline 5. & Passion for teaching & $\begin{array}{c}\text { Middle School Teachers in } \\
\text { Italy }\end{array}$ & (Mo, 2016) \\
\hline 6. & $\begin{array}{l}\text { The pressure experienced by } \\
\text { teachers }\end{array}$ & Sports teacher in Spain & $\begin{array}{c}\text { (Cuevas, Ntoumanis, } \\
\text { Fernandez-Bustos, \& } \\
\text { Bartholomew, 2018) }\end{array}$ \\
\hline 7. & Teaching Coping & Teacher in Australia & $\begin{array}{c}\text { (Parker, Martin, Colmar, \& } \\
\text { Liem, 2012) }\end{array}$ \\
\hline 8. & $\begin{array}{c}\text { Job demands, } \\
\text { resources, and worsonal } \\
\text { resources }\end{array}$ & $\begin{array}{l}\text { Kindergarten, elementary, and } \\
\text { junior high school } \\
\text { teachers in Madrid }\end{array}$ & $\begin{array}{c}\text { (Bermejo, Hernández-Franco, } \\
\text { \& Prieto-Ursúa, 2013) }\end{array}$ \\
\hline 9. & Job demands and job resources & $\begin{array}{c}\text { Elementary, middle and high } \\
\text { school teachers in Madrid }\end{array}$ & $\begin{array}{c}\text { (Bermejo-Toro, Prieto-Ursúa, } \\
\text { \& Hernández, 2016) }\end{array}$ \\
\hline 10. & Teacher Efficacy & $\begin{array}{c}\text { Elementary and middle school } \\
\text { teachers in Hong Kong }\end{array}$ & (Huang \& Yin, 2018) \\
\hline 11. & Social, emotional learning & $\begin{array}{l}\text { Kindergarten teacher at United } \\
\text { State }\end{array}$ & $\begin{array}{c}\text { (Zinsser, } \text { Christensen, } \quad \& \\
\text { Torres, 2016) }\end{array}$ \\
\hline 12. & Resilience & Teacher in Germany & $\begin{array}{l}\text { (Pretsch, Flunger, \& Schmitt, } \\
\text { 2012) }\end{array}$ \\
\hline 13. & $\begin{array}{l}\text { Workload, injustice, and work- } \\
\text { family conflict }\end{array}$ & Teacher in Italy & $\begin{array}{l}\text { (Guglielmi, Panari, \& Simbula, } \\
\text { 2012) }\end{array}$ \\
\hline 14. & Autonomy & Kindergarten teacher in Canada & (Royer \& Moreau, 2016) \\
\hline 15. & $\begin{array}{l}\text { Organizational culture and } \\
\text { organizational } \\
\text { commitment }\end{array}$ & $\begin{array}{l}\text { An elementary teacher in } \\
\text { Beijing }\end{array}$ & (Zhu, Devos, \& Li, 2011) \\
\hline 16. & $\begin{array}{l}\text { Personality and organizational } \\
\text { climate }\end{array}$ & $\begin{array}{l}\text { Teachers in rural and urban } \\
\text { areas in Norway }\end{array}$ & (Burns \& Machin, 2012) \\
\hline 17. & Emotional intelligence & Teacher in Pakistan & (Farhan \& Ali, 2016) \\
\hline 18. & Spiritually & Catholic teacher in India & (Clarence \& George, 2018) \\
\hline 19. & Job demands & $\begin{array}{l}\text { The elementary school teacher } \\
\text { in Croatia }\end{array}$ & $\begin{array}{l}\text { (Tadić, Bakker, \& Oerlemans, } \\
\text { 2015) }\end{array}$ \\
\hline 20 & Teacher work stress & Kindergarten teacher in Beijing & (Li \& Zhang, 2019) \\
\hline
\end{tabular}

\subsection{RESEARCH FINDINGS}

The synthesis of the study results shows that the well-being of teachers in the workplace is determined by personal, professional, and organizational factors. More details are presented in the following Figure 1: 


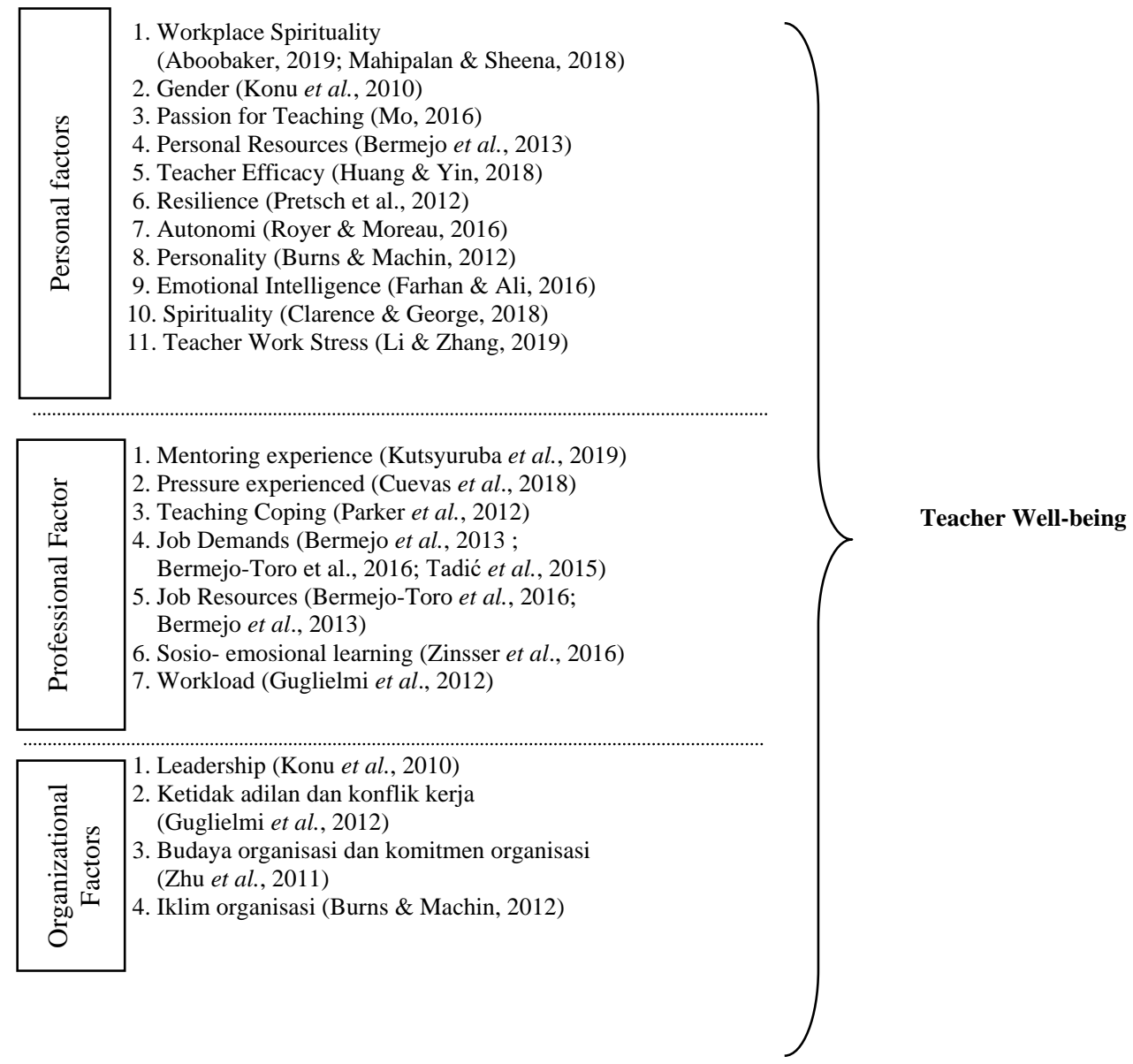

Figure 1 Synthesis of research results

\subsection{DISCUSSION}

Several factors that become the predictor variables of teacher well-being can be grouped into personal factors, professional factors, and organizational factors. In the paradigm of psychology, human development can be predicted from factors within the individual (determinant factors) and environmental factors (ecology). Several studies have found various personal characteristics as predictors of the achievement of well-being teachers in schools. Educating activities cannot be separated from spirituality aspects (Sandhu, 2015) because teaching work requires calls from outside human strength (Kumar, 2018). Spirituality is a fundamental part of human personality, so individuals who have a strong foundation of spirituality can be consistent in achieving organizational goals. From the research, it was found that workplace spirituality influences the well-being of teachers because workplace spirituality can allow teachers to experience meaning and purpose in their work, a sense of community through positive relationships, and the alignment of personal and organizational values may be one of the most managerial tasks important meaningful work has the most significant influence on well-being in the workplace. Someone who involves workplace spirituality in working or interacting with coworkers will feel some of the group who feel trusted, valued, and supported by their coworkers so that an understanding of workplace spirituality makes someone more caring, enthusiastic, creative, and can increase work intensity (Aboobaker, 2019; Clarence \& George, 2018; Mahipalan \& Sheena, 2018). Therefore teachers must involve their workplace spirituality to improve their work product to have a good impact on the work environment (Rachmah, 2016).

Personal factors also prove that Personal Resources help teachers ease the workload, achieve goals, and encourage the teaching profession's development (Burns \& Machin, 2012). Self-efficacy is considered an essential part of personal factors because, with selfconfidence, the teacher will manage themselves and work resources (Bermejo-Toro et al., 2016). In professional aspects, work demands and workloads are predictors of teacher well-being. Teachers who work in rural schools have different work demands than teachers who teach in urban schools. Likewise, teachers who teach many classes have different workloads than teachers who teach in schools with few students. Therefore, future researchers' well-being teachers need to pay attention to the school environment's factors, both the physical and social environment.

Organizational factors also prove to be predictors of teachers' well-being in schools (Parent-Lamarche \& Marchand, 2019). In organizational theory, school as an organization has four aspects: organizational goals, organizational climate, organizational structure, and organizational context, related to how schools establish communication with various parties (Bush, 2015). The theory used as the basis for studying environmental influences is an ecological theory that holds that to understand human development, one must consider the entire ecological system in which development occurs. The environment around individuals is a system layer that is constantly changing and can 
affect individuals (Bronfenbrenner, 1994). The work environment directly affects work, but other ecological contexts such as family and society can also change the system in which individuals are located (Krueger, 2005).

Thus personal factors and environmental factors, especially the organizational environment, cannot be separated to predict the teacher's well-being. But most of the results of the study have not combined personal factors with organizational factors, except the results of research by Bermejo et al. (2013), which combines the variable job demands and job resources as well as Burns \& Machin (2012), which combines personality variables and organizational climate. The achievement of well-being is determined by the interaction between personal factors and the environment $(\mathrm{Ng} \&$ Fisher, 2013). Schools are one of the organizational units whose role is to determine teacher professionalism. If school organizations are less effective, teacher well-being will be hampered (Holmes, 2005). The multilevel determinant model explains that individuals who experience organizational stress will mobilize their internal resources to deal with them and avoid depleting resources (Marchand, Durand, Haines, \& Harvey, 2015). This finding also reinforces that research that combines personal factors with organizational factors will reference teacher resource development. The teacher is in an environment that is a dynamic system and contains various strengths if various aspects of power in the joining climate will affect the teachers' condition in the system.

\subsection{CONCLUSION}

This systematic review synthesizes factors that are predicted to influence the well-being of teachers in schools. Personal, professional, and organizational factors are proven to determine the achievement of teacher well-being. Not many researchers thoroughly examine these three factors, and most researchers partially consider these three factors. Future researchers recommend exploring personal, professional, and organizational factors together as predictors of teacher well-being.

\section{References}

Aboobaker, N. (2019). Workplace Spirituality, Employee Wellbeing, and Intention to Stay : A multi-group analysis of teachers' Career Choice International Journal of Educational Management Article Information : International Journal of Educational Management, 33(1), 28-44. https://doi.org/10.1108/IJEM-02-2018-0049

Acton, R., \& Glasgow, P. (2015). Teacher Well-being in Neoliberal Contexts : A Review of the Literature. Australian Journal of Teacher Education, 40(8), 99-114.

Awan, S., \& Sitwat, A. (2014). Workplace Spirituality, Self-esteem, and Psychological Well-being Among Mental Health Professionals. Pakistan Journal of Psychological Research, 29(1), 125-149.

Bahari, F.B., Lin, T. A., \& Wider, W. (2016). The Effect of Occupational Stress on Teachers' Psychological Well-Being: Social Support As Moderator. Australian Journal of Basic and Applied Sciences, 10 (February), 54-65.

Bermejo-Toro, L., Prieto-Ursúa, M., \& Hernández, V. (2016). Towards a Model of Teacher Well-Being: Personal and Job Resources Involved in Teacher Burnout and Engagement. Educational Psychology, 36(3), 481-501. https://doi.org/10.1080/01443410.2015.1005006

Bermejo, L., Hernández-Franco, V., \& Prieto-Ursúa, M. (2013). Teacher Well-being: Personal and Job Resources and Demands. Procedia - Social and Behavioral Sciences, 84, 1321-1325. https://doi.org/10.1016/j.sbspro.2013.06.750

Bower, J.M., \& Carroll, A. (2017). Capturing Real-Time Emotional States And Triggers For Teachers Through The Teacher Well-Being Web-Based Applicationt: A Pilot Study. Teaching and Teacher Education, 65, 183-191. https://doi.org/10.1016/j.tate.2017.03.015

Bronfenbrenner, U. (1994). Ecological Models of Human Development. International Encyclopedia of Education (2nd ed.). Oxford: Elsevier Ltd. https://doi.org/10.1007/978-0-387-79061-9_437

Burns, R.A., \& Machin, M.A. (2012). Employee and Workplace Well-being : A Multilevel Analysis of Teacher Personality and Organizational Climate in Norwegian Teachers from Rural, Urban and City Schools. Scandinavian Journal of Educational Research, (January), 1-16. https://doi.org/10.1080/00313831.2012.656281

Bush, T. (2015). Organization Theory in Education: How Does It Inform School Leadership? Journal of Organizational Theory in Education, 1(1), 35-47. Retrieved from http://www.organizationaltheoryineducation.com/index.php/jote/article/view/19 Retrieved date: 28 December 2020.

Clarence, M., \& George, T.S. (2018). Spirituality and Subjective Well-Being Among Catholic College Teachers of Bangalore. Indian Journal of Health and WellBeing, 9(4), 678-680

Collie, R.J., Shapka, J.D., Perry, N., \& Martin, A.J. (2015). Teacher Well-Being: Exploring Its Components and a Practice-Oriented Scale. Journal of Psychoeducational Assessment, 33, 744-756. https://doi.org/10.1177/0734282915587990.0

Cuevas, R., Ntoumanis, N., Fernandez-Bustos, J.G., \& Bartholomew, K. (2018). Does Teacher Evaluation Based on Student Performance Predict Motivation, WellBeing, And Ill-Being? Journal of School Psychology, 68(March), 154-162. https://doi.org/10.1016/j.jsp.2018.03.005

Danna, K., \& Griffin, R.W. (1999). Health and Well- Being in the Workplace : A Review And Synthesis of the Literature. Journal of Management, 25(3), 357-384. https://doi.org/10.1177/014920639902500305

Deci, E.L., \& Ryan, R.M. (2008). Hedonia, Eudaimonia, And Well-Being: An Introduction. Journal of Happiness Studies, 9, 1-2. https://doi.org/10.1007/s10902-0069018-1

Dundar, Y., \& Fleeman, N. (2017). Applying Inclusion and Exclusion Criteria. In A. Boland, G.M. Cherry, \& R. Dickson (Eds.), Doing a Systematic Review: A Student's Guide, 79-92. Los Angeles: Sage Publications.

Elovainio, M., Pietikäinen, M., Luopa, P., Kivimäki, M., Ferrie, J.E., Jokela, J., Virtanen, M. (2011). Organizational Justice at School and its Associations with Pupils' Psychosocial School Environment, Health, and Well-Being. Social Science and Medicine, 73(12), 1675-1682. https://doi.org/10.1016/j.socscimed.2011.09.025

Farhan, S., \& Ali, A.Z. (2016). Emotional Intelligence as a Predictor of Self Efficacy and Subjective Well Being among University Teachers of Public Sector. Bahria Journal of Profesional Psychology, 15(2), 23-38. https://doi.org/10.1017/CBO9781107415324.004

Fisher. D Cynthia. (2014). Conceptualizing and Measuring Well-being at Work. In Peter Y. Chen \& Cary L. Cooper. (Eds.), Well-being: A Complete Reference Guide, Volume III. New Jersey: John Wiley \& Sons, Ltd. Published. https://doi.org/10.1002/9781118539415.wbwell02

Forest, J., Mageau, G.A., Crevier-braud, L., Bergeron, É., \& Dubreuil, P. (2012). Human Relations. Human Relations, 65(9), 1233-1252. https://doi.org/10.1177/0018726711433134

Graham, A., \& Truscotthttps, J. (2019). Meditation in the Classroom: Supporting Both Student And Teacher Well-Being? Education 3-13, O(0), 1-13. https://doi.org/10.1080/03004279.2019.1659385

Guglielmi, D., Panari, C., \& Simbula, S. (2012). The Determinants of Teachers' Well-Being: The Mediating Role of Mental Fatigue. European Journal of Mental Health, 7(2), 204-220. https://doi.org/10.5708/EJMH.7.2012.2.3

Hapsari, I.I. dan M. (2016). Empati dan Motivasi Kerja Guru Sekolah Luar Biasa. Jurnal Penelitian Dan Pengukuran Psikologi, 5(1), $48-56$.

Holmes, E. (2005). Teacher Well-being, Looking after Yourself and Your Career in the Classroom. New York: Taylor and Francis Group.

Huang, S., \& Yin, H. (2018). Teacher Efficacy and Affective Well-Being in Hong Kong: An Examination of Their Relationships and Individual Differences. ECNU Review of Education, 1(2), 102-126. https://doi.org/10.30926/ecnuroe2018010205 
Huta, V. (2015). An Overview of Hedonic and Eudaimonic Well-Being Concepts. In L. Reinecke \& M. B. Oliver (Eds.), Handbook of Media Use And WellBeing. (Issue Nopember). Routledge

Hwang, Y., Noh, J.-E., Medvedev, O., \& Singh, N. (2019). Effects of a Mindfulness-Based Program for Teachers on Teacher Wellbeing and Person-Centered Teaching Practices. Mindfulness, 10(September), 1-18. https://doi.org/https://doi.org/10.1007/s12671-019-01236-1

Konu, A., Viitanen, E., \& Lintonen, T. (2010). Teachers' Well-Being and Perceptions of Leadership Practices. International Journal of Workplace Health Management, 3(1), 44-57. https://doi.org/10.1108/17538351011031939

Krueger, M. (2005). Four Themes in Youth Work Practice. Journal of Community Psychology, 33(1), 21-29. https://doi.org/10.1002/jcop.20033

Kumar, S. (2018). A Study of Perceived Workplace Spirituality of School Teachers. Psychological Thought, 11(2), 212-223. https://doi.org/10.5964/psyct.v11i2.298

Kutsyuruba, B., Godden, L., \& Bosica, J. (2019). The Impact of Mentoring on the Canadian Early-Career Teachers' Well-Being. International Journal of Mentoring and Coaching in Education, 8(4), 285-309. https://doi.org/10.1108/IJMCE-02-2019-0035

Li, Y., \& Zhang, R.C. (2019). Kindergarten Teachers' Work Stress and Work-Related Well-Being: A Moderated Mediation Model. Social Behavior and Personality, 47(11), 1-12. https://doi.org/10.2224/sbp.8409

Liang, J., Peng, L., Zhao, S., \& Wu, H. (2017). Relationship among Workplace Spirituality, Meaning in Life, and Psychological Well-being of Teachers. Universal Journal of Educational Research, 5(6), 1008-1013. https://doi.org/10.13189/ujer.2017.050613

Mafazi, A. dan D. (2016). Efikasi dan Kesejahteraan Psikologis Pada Guru SMP. Jurnal Penelitian dan Pengukuran Psikologi, 5(2), 77-84.

Mahipalan, M., \& Sheena. (2018). Workplace Spirituality and Subjective Happiness Among High School Teachers: Gratitude As A Moderator. The End-to-End Journal, 15(2), 107-114. https://doi.org/10.1016/j.explore.2018.07.002

Marchand, A., Durand, P., Haines, V., \& Harvey, S. (2015). The Multilevel Determinants Of Workers' Mental Health: Results from the SALVEO study. Social Psychiatry and Psychiatric Epidemiology, 50(3), 445-459. https://doi.org/10.1007/s00127-014-0932-y

Mo, A. (2016). Harmonious Passion and Its Relationship with Teacher Well-Being. Teaching and Teacher Education, 59, 431-437. https://doi.org/10.1016/j.tate.2016.07.017

Ng, E.C.W., \& Fisher, A.T. (2013). Understanding Well-Being in Multi-Levels: A Review. Health, Culture, and Society, 5(1), 308-323. https://doi.org/10.5195/hcs.2013.142

Parent-Lamarche, A., \& Marchand, A. (2019). Well-Being At Work From A Multilevel Perspective: What Is The Role Of Personality Traits? International Journal of Workplace Health Management, 12(5), 298-317. https://doi.org/10.1108/IJWHM-05-2019-0066

Parker, P.D., Martin, A.J., Colmar, S., \& Liem, G.A. (2012). Teachers' Workplace Well-Being: Exploring A Process Model of Goal Orientation, Coping Behavior, Engagement, and Burnout. Teaching and Teacher Education, 28(4), 503-513. https://doi.org/10.1016/j.tate.2012.01.001

Pretsch, J., Flunger, B., \& Schmitt, M. (2012). Resilience Predicts Well-Being in Teachers But Not in Non-Teaching Employees. Social Psychology of Education, 15(3), 321-336. https://doi.org/10.1007/s11218-012-9180-8

Qudsyi, H. dan F. (2015). Perbedaan Subjective Well Being Antara Guru Bersertifikasi dan Non Sertifikasi. Jurnal RAP UNP, 6(2), 126-135.

Rachmah, E.N. (2016). Pengaruh Social Capital dan Workplace Spirituality Terhadap Employee Engagement. Jurnal Psikologi, 2(0), 375-386.

Renshaw, T.L., Long, A.C.J., \& Cook, C.R. (2015). Assessing Teachers' Positive Psychological Functioning at Work: Development and Validation of the Teacher Subjective Wellbeing Questionnaire. School Psychology Quarterly, 30(2), 289-306.

Royer, N., \& Moreau, C. (2016). A Survey of Canadian Early Childhood Educators' Psychological Well-being at Work. Early Childhood Education Journal, 44(2), 135-146. https://doi.org/10.1007/s10643-015-0696-3

Sandhu, D. (2015). Workplace Spirituality: A New Paradigm for Teachers. Paripex - Indian Journal of Research, 4(8), 4-5. https://doi.org/10.5539/ijbm.v6n5p41

Sasmoko, S., Herisetyantri, I., Suroso, J.S., \& Ying, Y. (2017). Am I A Well-Being Teacher? ( A Review Of Subjective Well-Being For Elementary Teachers ). Man in India, 97(19), 293-300.

Shabir, M. U. (2015). Kedudukan Guru Sebagai Pendidik (Tugas dan Tanggung Jawab, Hak dan Kewajiban, dan Kompetensi Guru). Jurnal Pendidikan, 2(2), 221232.

Shrestha, A. K. (2016). Further Validation of Workplace Spirituality Scale in an Eastern Context. Journal of Business and Management Research, 1(1), 1-13. https://doi.org/10.3126/jbmr.vli1.14547

Spilt, J.L., Koomen, H.M.Y., \& Thijs, J.T. (2011). Teacher Well-being: The Importance of Teacher-Student Relationships. Journal Education Psychology, 23(0), 457-477. https://doi.org/10.1007/s10648-011-9170-y

Stanculescu, E. (2014). Psychological Predictors and Mediators of Subjective Well-being in a Sample of Romanian Teachers. Revista de Cercetare Si Interventie Sociala, 46, 37-52

Tadić, M., Bakker, A.B., \& Oerlemans, W.G.M. (2015). Challenge Versus Hindrance Job Demands And Well-Being: A Diary Study On The Moderating Role Of Job Resources. Journal of Occupational and Organizational Psychology, 88(4), 702-725. https://doi.org/10.1111/joop.12094

Tennant, J.E., Demaray, M.K., Malecki, C.K., Terry, M.N., Clary, M., \& Elzinga, N. (2015). Students' Ratings Of Teacher Support And Academic And SocialEmotional Well-Being. School Psychology Quarterly, 30(4), 494-512. https://doi.org/10.1037/spq0000106

Virtanen, T.E., Vaaland, G.S., \& Ertesvåg, S.K. (2019). Associations Between Observed Patterns of Classroom Interactions and Teacher Well-Being in Lower Secondary School. Teaching and Teacher Education, 77, 240-252. https://doi.org/10.1016/j.tate.2018.10.013

Warr, P. (1994). A Conceptual Framework for the Study Of Work And Mental Health. Work and Stress, 8(2), 84-97. https://doi.org/10.1080/02678379408259982

Waterman, A. S. (1993). Two Conceptions of Happiness : Contrasts of Personal Expressiveness ( Eudaimonia ) and Hedonic Enjoyment. Journal of Personality and Social Psychology, 64(4), 678-691. https://doi.org/10.1037/0022-3514.64.4.678

Wulan, D.K., \& Putri, M. (2016). Job Demands Dan Workplace Well- Being Pada Guru Sekolah Luar Bisa. Jurnal Penelitian Dan Pengukuran Psikologi, 5(1), 28-38.

Zhu, C., Devos, G., \& Li, Y. (2011). Teacher Perceptions Of School Culture And Their Organizational Commitment And Well-Being In A Chinese School. Asia Asia Pacific Education ReviewAsia Pacific Education Review, 12(2), 319-328. https://doi.org/10.1007/s12564-011-9146-0

Zinsser, K.M., Christensen, C.G., \& Torres, L. (2016). She's Supporting Them; Who's Supporting Her? Preschool Center-Level Social-Emotional Supports and Teacher Well-Being. Journal of School Psychology, 59, 55-66. https://doi.org/10.1016/j.jsp.2016.09.001 